УДК $346.9+349.6$

DOI https://doi.org/10.32837/pyuv.v0i5.929

A. I. Лига

orcid.org/0000-0002-5171-747X

провідний еконоліст

Державної установи «Інститут еконоліко-правових досліджень ілені В. К. Мамутова Національної акаделї наук України»

\title{
РОЗВИТОК ЕКОЛОГІЧНОЇ СИСТЕМИ В КОНТЕКСТІ РАЦІОНАЛІЗАЦЇ МОДЕЛЕЙ СПОЖИВАННЯ ТА ЗАПОБІГАННЯ ОМАНЛИВІЙ ГОСПОДАРСЬКІЙ ПРАКТИЦІ "GREENWASHING"
}

Постановка проблеми. Сьогодні у сфері екологічної безпеки переважно виділяють три основних типи походження екологічних загроз.

До них відносять загрози від матеріального виробництва, від нераціональних моделей споживання та з боку безвідповідального (недостатньо відповідального) поводження з відходами.

При цьому навіть побіжний аналіз вітчизняних наукових праць, нормативно-правових актів та рішень органів влади дозволяє зробити висновок, що основна їх частина спрямована на врегулювання питань матеріального виробництва та поводження з відходами.

Питання раціонального споживання вочевидь розглядається як другорядне, переважно з позиції екологічної освіти та інформування споживачів, а також екологічного та органічного маркування. 3 такою другорядністю важко погодитись якщо враховувати формулювання загальновідомого економічного закону про те, що «попит народжує пропозицію». Значення свідомого споживчого вибору та попит на екологічно нейтральні товари впливає і на виробництво, і на відходи, тому є ключовим для розв'язання екологічних проблем.

Попри те, що екологічне (природоохоронне) законодавство враховує важливість раціонального споживання, екологічної освіти та інформування споживачів, ці положення переважно лишаються декларативними, адже не підкріплюються ані реальними механізмами їх реалізації, ані належною відповідальністю за їх порушення. Вітчизняне природоохоронне законодавство переважно концентрується на питаннях прямої шкоди природі та здоров'ю людей, тоді як непрямій шкоді від омани споживачів щодо екологічних характеристик продукції уваги майже не приділяється.

Особливо це актуально в контексті недостатнього запобігання оманливій господарській практиці "greenwashing", яка не тільки завдає необгрунтованих економічних втрат екологічно свідомим споживачам, але і підриває їх довіру до екологічного та органічного маркування та врешті решт до всього ринку «екологічних» товарів.

Відповідно, це знищує матеріальну основу для розвитку та вдосконалення екологічного та орга- нічного виробництва, створюючи проблеми зі збутом продукції. Адже підприємства, що залучені до такого виробництва, природно несуть значно більші витрати для її виготовлення порівняно 3 тими, що використовують оманливу практику, тому не можуть конкурувати за ціною, але через зневіру споживачів до ринку вони втрачають переваги, які дає екологічність у просуванні товарів на ринок.

Отже, така непряма за своєю суттю шкода може мати наслідки для екологічної безпеки, вищі за пряму шкоду, оскільки вона руйнує суспільний запит на екологічні товари.

Важливість запобігання нераціональному споживанню та загроз ринку екологічних товарів 3 боку оманливої господарської практики "greenwashing" визначає необхідність дослідження проблеми з'ясування можливості правозастосування українського природоохоронного законодавства в вищезазначеному контексті.

Аналіз останніх досліджень i публікацій. Останніми роками проблематиці раціоналізації моделей споживання та запобігання оманливій господарській практиці “greenwashing” були присвячені роботи низки науковців.

Так, дослідженню енергетичної моделі сталого споживання теплової енергії було присвячено роботу К.О. Братковської, яка вважає, що «енергетична модель сталого споживання має відбивати принципи організації ринку теплової енергії і виділяти зони з мінімальними інтегральними витратами на теплопостачання». Це, на її думку, дозволить «споживачам теплової енергії досягнути енергоефективності та вплинути на окремих виробників для підвищення ефективності їх функціонування» [1].

Колектив авторів А.В. Лесь, А.В. Ращенко, В.О. Смаглій у статті «Відповідальне споживання в умовах сталого розвитку» обґрунтували концептуальні засади сталого споживання, умовно розподілив їх на три блоки: харчування, ресурси у побуті, шопінг та поводження з відходами [2].

Автори статті «Використання грінвошингу як технології екологізації бізнесу: поняття, детермінанти та драйвери» О.Ф. Грищенко та Є.О. Голишева визначили, що "greenwashing" - виступає 
чинником, що здатний обмежувати процес побудови у споживачів шаблонів екологічно свідомої поведінки та значно спотворюе факти у процесі прийняття споживацьких рішень. У масиві інформації про продукти та послуги споживачі повинні не тільки оцінити всі їх переваги та недоліки, а й розпізнати неправдиві твердження та необгрунтовані претензії. За таких умов деякі компанії активно інвестують в екологічний імідж, упроваджуючи екологічні ініціативи, та запроваджують екологічні тренди, а інші компанії зосереджуються тільки на заявах, щодо екологічності без жодного практичного підгрунтя». Також у статті автори визначили кілька основних типів комунікацій за критерієм імплементації екологічного звернення практики "greenwashing” та сутність екологічних претензій (позовів) до таких практик [3].

У статті S. B. Fiialka "Greenwashing in communication with consumers on the ukrainian market" були досліджені та проаналізовані заяви про екологічність товарів на українському ринку, зробивши висновки, що наявні заяви на українському ринку свідчать про перевагу застосування практик Greenwashing над дійсно екологічно нейтральними товарами [4].

Результати аналізу Т. Пімоненко, О. Люльов, Л. Люльова, наведені в статті "Marketing instruments to promote green investment: declining greenwashing", показали, що одним з факторів, які обмежують ефективність промоції зелених інвестицій, є використання оманливої практики "greenwashing". У дослідженнях "greenwashing" визначається, як розрив між двома поведінками: найнижчим рівнем зеленої ефективності та декларацією зеленого іміджу. На думку авторів, з метою розвитку зеленого бренду країни, використання практики "greenwashing" повинно бути мінімізовано через контроль державних органів [5].

М.К. Міхайлуца, Н.О. Дугієнко в статті «Зелені інвестиції через зелені облігації» розвинули думку необхідності формування національних стандартів та інструкцій із «зеленого» маркування задля запобігання оманливій практиці “greenwashing”. Так, вони наголошують, що у світі виникла необхідність розробки GBP (Принципи зелених облігаціï). Це добровільні керівні процедурні принципи, призначені для широкого використання ринком, які рекомендують прозорість і розкриття інформації, а також сприяють екологічній чесності і результативності (integrity) ринку через використання національних правил і стандартів iз «зелених» облігацій, а також стандартів бухгалтерського обліку та звітності з перевірки облігаційного випуску на "greenwashing" [6].

Також вважаю доцільним використати результати власних досліджень за вказаною тематикою, викладені в статтях «Потенциал применения системы защиты прав потребителей для обеспе- чения экологической безопасности города» [7], «Розв'язання проблем 3 екологічної безпеки, в актах міжнародного права у сфері захисту прав споживачів», а також «Проблеми екологізації господарського права: в контексті усунення оманливої господарської практики "greenwashing”.

Визнаючи важливість та актуальність вищезазначених наукових праць у контексті визначених у них цілей, слід зауважити, що питання дослідження українського законодавства на предмет законодавчого забезпечення раціоналізації моделей споживання та запобігання оманливій господарській практиці “greenwashing” розкрита в них недостатньо, тому потребує більш грунтовного дослідження.

Мета статті - дослідити законодавче забезпечення впровадження раціональних моделей споживання та запобігання оманливій господарській практиці “greenwashing” в українському природоохоронному законодавстві, запропонувати практичні рекомендації їх правозастосування та вдосконалення.

Ця мета передбачає досягнення таких цілей:

1. Визначення основних завдань для законодавства в контексті забезпечення розвитку раціональних моделей споживання та запобігання оманливій господарській практиці "greenwashing”;

2. Дослідження вмісту основних природоохоронних нормативно-правових актів України на предмет їх впливу на ліквідацію загроз з боку нераціонального споживання;

3. Визначення можливості правозастосування українського законодавства в контексті вищезазначених завдань, а також органів влади, що уповноважені на їх вирішення.

4. Зробити висновки щодо основних недоліків законодавства в контексті зазначеної мети та надати пропозиції щодо їх усунення.

Результати дослідження. Для визначення завдань, що має вирішувати законодавство в контексти забезпечення розвитку раціональних моделей споживання, слід звернути увагу на джерела формування нераціонального споживання.

Головним джерелом є стара економічна концепція індустріального суспільства, яка в центр уваги ставила не потреби суспільства, а потреби матеріального виробництва.

Під час промислової революції 18-19 століть існувала економічна теорія, оформлена у «закон Ж.Б. Сэя», що саме «пропозиція породжує попит». Вважалось, що суспільство в будь-якому разі купить усе, що йому запропонує ринок. На початковому етапі ця теорія не суперечила дійсності, адже в доіндустріальну епоху існував істотний дисбаланс між реальними потребами суспільства та можливостями матеріального виробництва. Ручне виробництво просто фізично було неспроможне задовольнити потреби всіх споживачів у 
основних товарах та послугах, отже, головною перешкодою для тотального дефіциту в ту епоху була ціна товару та рівень добробуту громадян, який (для більшості) лишався на вкрай низькому рівні. Заміна ручного труда машинним зняла проблему насичення ринку достатньою для споживачів кількістю товарів, а її обсяги та інновації дозволяли істотно та постійно знижувати ціну, роблячи бажані товари та послуги доступнішими. Також постійно підвищувався рівень доходів населення, а оновлення виробництва та товарного асортименту викликало природно стабільний, чимраз вищий попит у населення. Тому характерною особливістю для тієї епохи стала поява нераціонального виробництва, коли суб'єкти господарювання орієнтувались не на реальні потреби суспільства, а на свої власні економічні прагнення. Але у другій чверті 20 сторіччя «закон Ж.Б. Сея» перестав діяти, адже рівень доходів населення істотно зріс та дозволив задовольнити реальні потреби споживачів. Суспільство перейшло до процесу накопичення, знизилась циркуляція фінансів, виникла криза перевиробництва, яка вилилась у «велику депресію».

Пояснення її причини знайшов Д.М. Кейнс, який сформував новий економічний закон, відповідно до якого «попит породжує пропозицію». Але індустріальна ідеологія того часу не змогла пристосувати інтереси виробництва до реальних потреб людей. Отже, було винайдено рішення у штучному стимулюванні попиту через створення штучних потреб та бажань у людей, розвитку практик споживчого кредитування, постійної зміни моди, використання оманливої реклами та недостовірної інформації для споживачів, штучного заниження якості та старіння товарів тощо.

На початку 70-х років, з розвитком громадянського суспільства, індустріальна ідеологія почала відмирати і їй на зміну стала приходити нова постіндустріальна ідеологія, де на перше місце стали виходити реальні потреби людини, захист їі інтересів та ліквідація негативного впливу на навколишнє середовище. В процесі їі розвитку сформувався «консюмеризм», завдання якого значною мірою збігаються 3 завданнями, що ставляться для охорони навколишнього середовища. Сьогодні «консюмеризм» стоїть на ідеології «зеленого та раціонального споживання», що ставить його у пряму опозицію до «штучного консюмеризму», створеного у індустріальному суспільстві для стимулювання нераціонального попиту, і який сповідує ідеологію «оніоманії» як залежності від процесу постійних нераціональних покупок.

Штучне розуміння «консюмеризму» 3'явилось приблизно в середині 20 сторіччя, коли, прикриваючи справжню причину надмірного споживання та нераціонального (хижацького) використання ресурсів у сучасній економіці, Джон Бугас, віце-президент "Ford Motor Company" у 1955, ввів термін «консюмеризм» замість «капіталізму», щоб краще описати американську економіку). На його думку, «це мало вирвати килим 3-під недружніх критиків, які так довго і голосно лаялися на капіталізм. Чомусь я просто не можу уявити, як вони кричать: «Геть споживачів!» [8].

Таким чином, основна причина нераціонального споживання полягає не стільки в нераціональних прагненнях споживачів до купівлі зайвих товарів, скільки в діяльності недобросовісних суб'єктів господарювання, що стимулюють нераціональність споживання.

Відповідно, заходи, спрямовані на зменшення практик нераціонального споживання, повинні спрямовуватись не тільки на виправлення нераціональної споживчої поведінки, але і на усунення з ринку недобросовісних господарських практик, які таку поведінку заохочують.

Розуміння необхідності кореляції підходів для боротьби з нераціональним споживанням можна виявити, якщо проаналізувати зміни у відповідній політиці ЄС.

До недавнього часу політика на рівні ЄС, орієнтована на боротьбу з нераціональним споживанням, була зосереджена на використанні інформаційних інструментів політики, щоб спробувати вплинути на нераціональну поведінку споживачів.

Для раціоналізації споживання до недавнього часу використовувались тільки засоби впливу на поведінку споживачів:

1. Екологічна та споживча освіта та просвіта;

2. Проведення кампаній з підвищення обізнаності споживачів щодо наслідків їх вибору;

3. Залучення агентів впливу на споживчу поведінку;

4. Впровадження екологічних критеріїв державних закупівель;

5. Інформаційне забезпечення споживачів, з наданням їм повної, своєчасної та достовірної інформації про продукцію;

6. Екологічне та органічне маркування товару.

Така політика безумовно дала свої результати з формування екологічного запиту до продукції 3 боку споживачів, але насправді мала недостатньо доказів того, що покращена інформація про екологічні показники продукції, зокрема екологічні маркування, призводить до реальних змін у купівельній поведінці, не кажучи вже про необхідний масштаб таких змін.

Отже, сьогодні політика ЄС змінюється також у бік стимулювання суб'єктів господарювання до зміни старої індустріальної капіталістичної логіки, що надає пріоритет ціні перед якістю, екологічністю та довговічністю продукції [9]. В результаті посилюються заходи державного та недержавного контролю (нагляду) за 
недобросовісним бізнесом та відповідальність за вчинення правопорушень.

Таким чином, для раціоналізації споживання додалися засоби впливу на поведінку суб'єктів господарювання потрібно вжити таких заходів:

1. Гармонізація та верифікація «зелених заяв» на внутрішньому ринку.

2. Стандартизація вимог екологічного або органічного маркування продукції за визначеними у законодавстві процедурами, верифікація та перевірка її відповідності, а також гарантія відповідальності за неналежне або оманливе екологічне або органічне маркування;

3. Підвищена увага до оманливих заяв у рекламі та маркетингу, їх перевірка та встановлення чіткої відповідальності.

4. Підвищення прозорості діяльності та звітності суб'єктів господарювання;

5. Заборони штучного старіння, та запровадження заходів спрямовані проти «швидкої моди" та інших практик, що перешкоджають довговічному використанню продукції;

6. Підвищення ролі практик екологічної корпоративної відповідальності та саморегулювання, долучення до екологічних стандартів;

7. Заходи сприяння суб'єктам господарювання які комплексно переглядають свою практику закупівель, виробництва, продажу та утилізації продукції;

8. Сприяння бізнес-моделям споживчої кооперації через поширення нової специфічної підприємницької форми, яка ставить реальні інтереси споживачів в основу господарської структури діяльності;

9. Посилення державного нагляду та впливу на ринок щодо виявлення та усунення з ринку оманливих господарських практик "greenwashing";

10. Долучення до нагляду за ринком недержавних інститутів (споживачі, профспілки, організації громадянського суспільства, асоціації бізнесу або навіть інші суб'єкти господарювання, постраждалі від недобросовісної екологічної конкуренціі) [10];

11. Встановлення адекватної (з нівелювальним економічним ефектом, залежно від розміру правопорушення) відповідальності за використання оманливої практики "greenwashing".

Таке посилення контролю та відповідальності стало особливо актуальним у контексті поширення оманливих та недобросовісних практик, які зростають відповідно до зростання екологічних запитів споживачів через використання оманливої практики "greenwashing".

У статтях О.Ф. Грищенко та Є.О. Голишева «Використання грінвошингу як технології екологізації бізнесу: поняття, детермінанти та драйвери» [3] та А.I. Лига «Проблеми екологізації господарського права: в контексті усунення оман- ливої господарської практики "greenwashing” достатньо ретельно було визначено основні прояви відповідної оманливої практики, які також називають «сім гріхів грінвошингу» [9].

Не зупиняючись на їх переліченні, варто зазначити, що загалом така практика може бути частково або повністю оманливою, надаючи нібито екологічній продукції відсутніх характеристик чи намагаючись значно завищити незначний екологічний ефект, відвертаючи увагу від значних неекологічних (або шкідливих) аспектів продукції.

Для виявлення та усунення з ринку оманливої господарської практики "greenwashing” використовують аналіз «зелених заяв» суб'єктів господарювання на відповідність екологічним цілям, які полягають у:

1) пом'якшенні наслідків зміни клімату;

2) адаптації до кліматичних змін;

3) стійкому використанню та охороні водних та морських ресурсів;

4) переходу до циркулярної економіки;

5) запобіганню та контролю забруднення;

6) захисті та відновленні біорізноманіття та екосистем.

На підставі цих екологічних цілей розроблено такі критерії, що характеризують виробництво кліматично нейтральної, екологічно стійкої та ресурсоефективної продукції:

(а) продукція вносить суттєвий внесок у досягнення однієї або кількох екологічних цілей;

(б) не завдає значної шкоди жодній з екологічних цілей;

(в) здійснюється 3 дотриманням мінімальних гарантій, встановлених законодавством щодо екологічно безпечної продукції;

(г) відповідає технічним критеріям перевірки, встановленим законодавством.

Невідповідність продукції вищезазначеним критеріям та екологічним цілям, за наявності у суб'єктів господарювання «зелених заяв» щодо такої продукції, дозволяє ідентифікувати оманливу господарську практику "greenwashing" та вжити низку господарських та адміністративно-господарських санкцій. При цьому за заведеною в законодавстві ЄС практикою розмір таких санкцій має повністю нівелювати можливість отримання будь-якого прибутку від оманливої діяльності [9].

Таким чином, для раціоналізації споживання та запобігання оманливій господарській практиці "greenwashing" сучасне законодавство має врегульовувати механізми правозастосування для всіх 17 зазначених вище засобів впливу на поведінку як споживачів, так і суб’єктів господарювання.

Отже, проаналізуємо вітчизняне екологічне законодавство в цьому контексті.

До основних природоохоронних законодавчих актів України належать: Лісовий кодекс України, 
Водний кодекс України, Земельний кодекс України, ЗУ «Про охорону навколишнього природного середовища», ЗУ «Основні засади (стратегія) державної екологічної політики України на період до 2030 року», ЗУ «Про державну систему біобезпеки при створенні, випробуванні, транспортуванні та використанні генетично модифікованих організмів», ЗУ «Про екологічну мережу України», ЗУ «Про екологічний аудит», ЗУ «Про охорону земель», ЗУ «Про питну воду та питне водопостачання», ЗУ «Про відходи», ЗУ «Про екологічну експертизу», ЗУ «Про основні принципи та вимоги до органічного виробництва, обігу та маркування органічної продукції», а також Закони про ратифікацію низки міжнародних конвенцій (зокрема, ЗУ «Про ратифікацію Кіотського протоколу до Рамкової Конвенції Організації Об’єднаних Націй про зміну клімату») тощо.

Але щодо їх впливу на ліквідацію загроз з боку нераціонального споживання товарів та запобігання оманливій господарській практиці "greenwashing” певний вплив мають лише деякі з них.

Отже, до таких актів слід віднести: ЗУ «Про охорону навколишнього природного середовища», ЗУ «Основні засади (стратегія) державної екологічної політики України на період до 2030 року», ЗУ «Про основні принципи та вимоги до органічного виробництва, обігу та маркування органічної продукції» .

Відповідно до ЗУ «Про охорону навколишнього природного середовища" до завдань законодавства про охорону навколишнього природного середовища, визначених у статті 1 , належать завдання щодо регулювання відносин у галузі використання і відтворення природних ресурсів, забезпечення екологічної безпеки, запобігання і ліквідації негативного впливу господарської та іншої діяльності на навколишнє природне середовище.

Попри загальність цього формулювання, очевидно, що вона спрямована на наслідки з боку матеріального виробництва, а не наслідки з боку нераціонального споживання.

Серед визначених у статті 3 зазначеного Закону принципів охорони навколишнього природного середовища в контексті нераціонального споживання без застережень можна застосувати лише принцип щодо «формування у населення екологічного світогляду».

Подібну ситуацію можемо знайти, досліджуючи статтю 9 щодо екологічних прав громадян України. Лише пункт (в) містить згадку щодо необхідності раціонального і комплексного використання природних ресурсів. Але його спрямовано не на раціоналізацію споживання з боку населення, а на раціоналізацію матеріального виробництва.

Так само контроль за раціональністю використання природних ресурсів у контексті мате- ріального виробництва визначено у завданнях Центрального органу виконавчої влади в цій сфері. Про це свідчить аналіз Положення про Державну екологічну інспекцію України, де питання нераціонального споживання, обмеження та запобігання оманливій господарській практиці "greenwashing" не входять до його компетенції.

Повертаючись до екологічних прав громадян, визначених у статті 9 3У «Про охорону навколишнього природного середовища», можна відмітити деякі з прав, за умови їх доповнення якими можна було застосувати до врегулювання питань цього дослідження, зокрема:

Пункт (е) щодо вільного доступу до екологічної інформації доповнити вимогами щодо її повноти, своєчасності та достовірності.

Пункт (ж) щодо права на одержання екологічної освіти доповнити положеннями гарантій такої освіти у період навчання та подальшої просвіти впродовж життя, а також посиланнями на нормативні акти, що визначають критерії такої освіти;

Зміст пункту (л) статті 68 щодо відповідальності за відмову у наданні своєчасної, повної та достовірної інформації, а також за фальсифікацію відомостей щодо стану навколишнього природного середовища, джерел забруднення, стану екологічної обстановки чи захворюваності населення [11] доцільно розширити в контексті запобігання нераціональному споживанню та оманливій господарській практиці "greenwashing".

Також аналіз пунктів (з) (и) статті 9 та статей 10,11, 15, 68 свідчить про їх спрямованість на відшкодування прямої шкоди, заподіяної здоров'ю та майну громадян внаслідок негативного впливу на навколишне природне середовище. Отже, за відсутності змін, що врахують непряму шкоду від оманливих практик через фіктивні екологічні заяви, що призводять до нераціонального вибору споживачів та підривають їхню довіру до ринку екологічних товарів, руйнуючи чесну конкуренцію, а також аналіз Закону України «Про охорону навколишнього природного середовища" дозволяє зробити висновок про слабку можливість для застосування його норм у контексті розв'язання проблеми цієї статті.

Цей Закон виключно орієнтовано на протидію прямій шкоді природному середовищу життю і здоров'ю людей, завданої матеріальним виробництвом.

Але в контексті цього дослідження вказаний закон дозволяє впливати на окремі аспекти матеріального виробництва через проголошення в статті 3 необхідності формування у населення екологічного світогляду.

Також серед екологічних прав громадян проголошено право на екологічну освіту та право на доступ до частини екологічної інформації без вимог до їі достовірності та встановлення відповідальності за їх порушення. 
Але загалом можемо зробити висновок, що вищезазначений Закон слабо пристосований для протидії нераціональному споживанню та оманливій практиці "greenwashing".

Недоліки Закону «Про охорону навколишнього природного середовища» е вищезазначеному контексті повністю продубльовано в «Положенні про Міністерство захисту довкілля та природних ресурсів України», затвердженому Постановою Кабінету Міністрів України від 25 червня 2020 р. № 614 .

Зміст цього положення свідчить про те, що Міністерство захисту довкілля та природних ресурсів України ані на рівні формування політик, ані на рівні визначення завдань Міністерства захисту довкілля та природних ресурсів України не розглядає питання раціоналізації споживання продукції (крім завдання раціоналізації використання ресурсів суб'єктами господарювання), екологічної освіти та просвіти, гармонізації, верифікації та нагляду за «зеленими заявами» на ринку екологічних товарів, координації діяльності органів влади, наукових та освітніх установ та громадського сектора та низки інших питань, що має значення для формування моделей раціонального споживання та запобігання оманливим практикам "greenwashing".

Аналіз Закону України «Про основні засади (стратегія) державної екологічної політики України на період до 2030 року» свідчить про більшу його пристосованість до кола питань, що досліджується.

Зокрема, в розділі першому зазначено, що першопричинами екологічних проблем України, зокрема, є:

- низький рівень розуміння в суспільстві пріоритетів збереження довкілля та переваг збалансованого (сталого) розвитку, недосконалість системи екологічної освіти та просвіти;

- незадовільний контроль за дотриманням природоохоронного законодавства та незабезпечення невідворотності відповідальності за його порушення;

- підпорядкованість екологічних пріоритетів економічній доцільності;

- неврахування наслідків для довкілля у законодавчих актах;

- неефективна система державного управління у сфері охорони навколишнього природного середовища, зокрема неузгодженість дій центральних і місцевих органів виконавчої влади та органів місцевого самоврядування.

Мету державної екологічної політики в Законі пропонується досягати через запровадження екосистемного підходу до всіх напрямів соціально-економічного розвитку України та збалансованого природокористування.

Серед визначених у Законі принципів реалізації засад державної екологічної політики виділя- ються наступні принципи, що впливають на раціоналізацію споживання та запобігання оманливій практиці "greenwashing":

- участь громадськості у формуванні державної політики;

- дотримання екологічних прав громадян;

- заохочення до ведення екологічно відповідального бізнесу та екологічно свідомої поведінки громадян;

- запобігання екологічній шкоді;

- міжнародна співпраця та євроінтеграція.

До основних інструментів реалізації державної екологічної політики віднесено:

- межсекторальне партнерство та залучення зацікавлених сторін (органи державної влади та органи місцевого самоврядування, суб'єкти господарювання, приватний сектор, науковці, громадськість);

- інформування та комунікація сприятимуть підвищенню рівня обізнаності громадськості про принципи та методи сталого споживання і виробництва, захисту довкілля;

- технічне регулювання та облік у сфері охорони навколишнього природного середовища, для впровадження науково обгрунтованих та безпечні для навколишнього природного середовища і здоров'я населення вимог до процесів, товарів та послуг, які відповідатимуть європейським нормам/вимогам;

- безперервність екологічної освіти в інтересах збалансованого (сталого) розвитку та розвиток всеохоплюючої екологічної просвіти;

- фінансові та економічні механізми, фінансування природоохоронної діяльності та стимулювання розвитку екологічного підприємництва, зокрема виробництво екологічної продукції, виконання робіт і надання послуг природоохоронного призначення, створення систем екологічного управління, впровадження більш чистого виробництва, технологій ресурсо- та енергозбереження, тощо; [12]

Також слід зазначити про три стратегічних цілі державної екологічної політики в контексті раціонального споживання, це:

Ціль 1. Формування в суспільстві екологічних цінностей і засад сталого споживання та виробництва;

Ціль 2. Забезпечення сталого розвитку природноресурсного потенціалу України;

Ціль 3. Забезпечення інтеграції екологічної політики у процес прийняття рішень щодо соціально-економічного розвитку України.

Таким чином, порівнюючи мету, цілі та принципи екологічної політики, визначені у Законі України «Про основні засади (стратегія) державної екологічної політики України на період до 2030 року», а також запропоновані інструменти ії реалізації з 17 визначеними вище засобами впливу 
на поведінку споживачів та суб'єктів господарювання, які ставляться в контексті раціоналізації споживання та усунення з ринку оманливої господарської практики "greenwashing” перед екологічною політикою в ЄС, можна зазначити, що в Законі охоплено більшість з зазначених завдань.

Неохопленими (частково неохопленими) лишились 8 таких завдань:

1. Забезпечення споживачів повною своєчасною та достовірною інформацією про продукцію;

2. Гармонізація та верифікація «зелених заяв» екологічного або органічного маркування на внутрішньому ринку;

3. Заборона оманливих заяв у рекламі та маркетингу, їх перевірка та встановлення чіткої відповідальності. Використання реклами та маркетингу для орієнтації споживачів на довговічність продукції та нові можливості використання старої продукції;

4. Прозорість діяльності та звітності суб’єктів господарювання;

5. Заборони штучного старіння та заходи, спрямовані проти швидкої моди та практик, що перешкоджають довговічному використанню продукції;

6. Посилення державного нагляду та впливу на ринок для виявлення та усунення с ринку оманливих господарських практик "greenwashing";

7. Долучення до нагляду за ринком недержавних інститутів (споживачі, профспілки, організації громадянського суспільства, асоціації бізнесу або навіть інші суб'єкти господарювання, постраждалі від недобросовісної екологічної конкуренції);

8. Встановлення адекватної (що нівелює економічний ефект від правопорушення) відповідальності за використання оманливої практики "greenwashing".

Таким чином, можна констатувати, що, попри істотне розширення в цьому Законі кола охоплених питань у контексті раціоналізації споживання, питання запобігання оманливій практиці “greenwashing” у цьому Законі фактично не знайшло свого відображення.

Крім того, слід зазначити, що і питання раціоналізації споживання в цьому Законі можна охарактеризувати як певний протокол про наміри. В ньому не зазначено конкретних виконавців, посилань на нормативні акти, через які досягаються проголошені цілі, та підстави для використання зазначених інструментів, а також відсутня відповідальність за їх невиконання (неналежне виконання).

Істотно відрізняється від проаналізованих законодавчих актів Закон України «Про основні принципи та вимоги до органічного виробництва, обігу та маркування органічної продукції» . В ньому формалізовані та конкретизовані норми, що запобігають оманливій господарській практиці “greenwashing” для органічних екологічних товарів.

У статті 2 Закону достатньо чітко визначено низку понять щодо різних типів органічної та неорганічної продукції, а також інших аспектів, важливих у контексті правозастосування цього Закону та уникнення можливостей для подвійного тлумачення.

У другому розділі Закону визначено права та обов'язки суб'єктів ринку органічної продукції, а поняттю органічного виробництва та порядку сертифікації такої продукції присвячені окремі розділи V та VI з високою деталізацією окреслених питань. Загалом позитивно характеризуючи їх зміст, не можна не зазначити, що серед прав суб’єктів ринку органічної продукції відсутнє право звертатись до органів державної влади 3 питань протидії недобросовісної конкуренції через розміщення на ринку оманливих заяв, реклами та товарів, що не відповідають вимогам цього Закону до органічної продукції.

Крім того, в Законі не приділена увага питанням освіти та просвіти споживачів щодо органічних продуктів, ідентифікації товарів державним логотипом для органічної продукції, можливостей та заборон стосовно інших видів маркування екологічної продукції та особливостям реклами органічної продукції.

Також у Законі не передбачено прав третіх сторін (зокрема споживачів), що також є певним недоліком, що підлягає врегулюванню.

Відповідно до Ст. 40 цього Закону відповідальність за порушення несуть всі основні суб'єкти господарювання у сфері органічного виробництва, обігу та маркування органічної продукції. До них належать оператори ринку, органи сертифікації, особи, які реалізують продукцію, марковану як органічна.

Оператори несуть відповідальність за такі правопорушення:

1) невиконання, несвоєчасне виконання законних вимог (приписів, розпорядчих актів) щодо усунення порушень вимог законодавства у сфері органічного виробництва, обігу та маркування органічної продукції;

2) ненадання, несвоєчасне надання або надання недостовірної інформації про обсяги органічної продукції, що вводиться в обіг;

3) маркування продукції державним логотипом для органічної продукції або використання у маркуванні позначень та написів «органічний», «біодинамічний», «біологічний», «екологічний», «органік» та/або будь-яких однокореневих та/або похідних слів від цих слів з префіксами біо-, екотощо будь-якими мовами за відсутності сертифіката, що засвідчує відповідність процесу виробництва продукції та її обігу вимогам законодавства 
у сфері органічного виробництва, обігу та маркування органічної продукції;

Органи сертифікації несуть відповідальність за:

1) невиконання, несвоєчасне виконання законних вимог (приписів, розпорядчих актів) щодо усунення порушень вимог законодавства у сфері органічного виробництва, обігу та маркування органічної продукції;

2) ненадання, несвоєчасне надання або надання недостовірної інформації, передбаченої цим Законом, або звіту про видані ними сертифікати;

3) порушення вимог цього Закону щодо сертифікації органічного виробництва та/або обігу органічної продукції, яке мало наслідком неправомірну видачу сертифіката;

4) повторне порушення вимог цього Закону щодо сертифікації органічного виробництва та/ або обігу органічної продукції, яке мало наслідком неправомірну видачу сертифіката;

Особи, які реалізують продукцію, марковану як органічна, несуть відповідальність за такі правопорушення:

1) введення в обіг або реалізація продукції без сертифіката, що засвідчує відповідність процесу виробництва продукції та/або її обігу вимогам законодавства у сфері органічного виробництва, обігу та маркування органічної продукції або вимогам законодавства держави походження такої продукції.

Водночас слід зазначити, що розмір штрафів не пропорційний розміру обороту та доходів.

Так, наприклад, неправомірне маркування продукції державним логотипом для органічної продукції або використання у маркуванні позначень та написів "органічний», «біодинамічний», «біологічний», «екологічний», «органік» та/або будь-яких однокореневих та/або похідних слів від цих слів з префіксами біо-, еко- тягне за собою накладення штрафу на юридичних осіб у розмірі восьми мінімальних заробітних плат, на фізичних осіб - підприємців - у розмірі п'яти мінімальних заробітних плат.

На нашу думку, застосування непропорційних штрафів, прив'язаних до обсягу виробленої продукції та розмірів неправомірно отриманої вигоди, не достатньо ефективне та утворює істотний дисбаланс відповідальності за великі та дрібні порушення. Так, у незначних самозайнятих фермерських господарствах штраф у п'ять чи вісім мінімальних заробітних плат за певних обставин може бути занадто високим, тоді як для недобросовісних промислових гігантів, що неправомірно виводять на ринок продукцію $з$ неправомірним органічним (екологічним) маркуванням на сотні мільйонів гривень, штраф у кілька десятків тисяч гривень буде дрібницею, яка цілком буде знівельована багатомільйонними неправомірними прибутками.
Загалом Закон України «Про основні принципи та вимоги до органічного виробництва, обігу та маркування органічної продукції» є достатньо збалансованим законодавчим актом, що дозволяє ефективно ідентифікувати та усувати з ринку оманливу практику "greenwashing” щодо органічних продуктів.

Водночас необхідно зазначити, що контроль за додержанням законодавства в цій сфері та право притягнення до відповідальності не належить до компетенції Державної екологічної інспекції України, а покладено на Державну службу України $з$ питань безпечності харчових продуктів та захисту споживачів. Таким чином, питання нагляду за виготовленням, маркуванням та розміщенням цього виду екологічних товарів на ринку органічних продуктів, законотворці надали не державним органам, на які покладено контроль за додержанням екологічного законодавства, а державному органу, що займається наглядом за ринком.

Питання екологічного маркування сьогодні українським законодавством майже не регулюється. До 11.01.2018 в Україні діяв «Технічний регламент з екологічного маркування», затверджений Постановою Кабінету Міністрів України від 18 травня 2011 р. N 529, який було скасовано через прийняття оновленої редакції Закону України «Про технічні регламенти та оцінку відповідності».

Зараз основними нормативно-правовими актами в цій сфері є ДСТУ ISO 14020:2003 Екологічнімаркування тадекларації.Загальніпринципи (ISO 14020:2000, IDT); ДСТУ ISO 14021:2016 Екологічні маркування та декларації. Самодекларації II типу (Екологічне маркування типу II) (ISO 14021:2016, IDT); ДСТУ ISO 14024:2002 Екологічні маркування та декларації. Екологічне маркування типу 1 . Принципи та методи (ISO 14024:1999, IDT).

Екологічна сертифікація здійснюється органом з оцінки відповідності за схемою, що відповідає вимогам ISO 14024.

Нагляд за сертифікованою продукцією та дотриманням правил застосування екологічного маркування здійснює орган з оцінки відповідності згідно з положеннями, викладеними в Угоді на право застосування екологічного маркування, та органи державного контролю (Антимонопольний комітет, Держпродспоживслужба) у порядку, передбаченому Законами України «Про захист економічної конкуренції, «Про захист прав споживачів» та «Про рекламу».

Нагляд за діяльністю органу з оцінки відповідності щодо його політики, цілей та результативності діяльності здійснює Координаційна рада з екологічного маркування. Підтвердження його компетентності, відповідно до вимог ISO/IEC 1706513, здійснює Національне агентство акредитації України [13]. 
Також слід зазначати, що, на відміну від органічних продуктів, за неправомірність екологічного маркування відповідальність для основних суб'єктів ринку екологічних товарів окремим законодавчим актом не встановлена. Також не визначено органу державної влади, до сфери діяльності якого належить функція нагляду за додержанням законодавства в цій сфері та притягнення до відповідальності за його порушення.

Оскільки недостовірність інформації порушує вимогу статті 15-1 (поширення інформації, що вводить в оману) Закону України «Про захист від недобросовісної конкуренції» певні механізми впливу на безпідставне застосування декларування екологічних характеристик чи переваг продукції в Україні існують.

За порушення цієї статті Антимонопольним комітетом України накладаються і стягуються штрафи в розмірі до 5\% від річного доходу за рік, що передував року, у якому виявлено порушення. Якщо доходу (виручки) немає, або відповідач на вимогу органів Антимонопольного комітету України, голови його територіального відділення не надав відомостей про розмір доходу (виручки), штраф, передбачений частиною першою цієї статті, накладається у розмірі до десяти тисяч неоподатковуваних мінімумів доходів громадян (Станом на вересень 2021 року під час застосування штрафів, адміністративних стягнень різними державними органами, податкових порушень, фінансових санкцій тощо, прив'язаних до неоподаткованого мінімуму доходів громадян, - його сума дорівнює 17 гривень [14]).

Попри те, що штраф у розмірі до $5 \%$ річного доходу пропорційний, але не можна не звернути увагу, що поняття до 5\% дозволяє тлумачення, що він може бути істотно меншим. При цьому не встановлена ані нижня величина штрафу, ані критерії, що визначають обставини, коли сума може бути зменшена, а це створює корупційні ризики та можливості істотного зменшення відповідальності.

До того ж, враховуючи відсутність прозорості розрахунків на ринку через необов'язковість застосування реєстраторів розрахункових операцій, приєднаних до бази серверів ДФС, сума санкцій за оманливе екологічне маркування може бути менше за 17000 грн, що є недостатньо адекватною сумою для припинення оманливої практики "greenwashing".

Також слід зазначити, що оскільки нагляд за екологічними товарами не є визначеною компетенцією Антимонопольного комітету України, то заходи його реагування в цій сфері не можуть мати системний характер, а цього недостатньо для належної протидії оманливим практикам на ринку екологічних товарів.

Аналізуючи відповідальність, передбачену природоохоронним законодавством, слід зазна- чити, що правова основа такої відповідальності встановлена статтею 68 Закону України «Про охорону навколишнього природного середовища», де зазначено, що порушення природоохоронного законодавства України тягне за собою дисциплінарну, адміністративну, цивільну і кримінальну відповідальність.

Адміністративна відповідальність за порушення природоохоронного законодавства передбачена главами 6 «Адміністративні правопорушення, що посягають на власність» та 7 «Адміністративні правопорушення у сфері охорони природи, використання природних ресурсів, охорони культурної спадщини» Кодексу України про адміністративні правопорушення (далі КУПАП).

За своїм змістом адміністративні порушення поділяються на:

1) правопорушення, що стосуються права власності на природні ресурси та перевищення лімітів їх використання (ст. ст. 47-50 та 91-2 КУпАП);

2) правопорушення, що стосуються незаконного використання, поводження та заволодіння земельними ділянками (ст. ст. 52-56 та 91КУпАП);

3) правопорушення вимог щодо охорони надр та незаконного видобутку (ст. 57-58-1 КУпАП);

4) правопорушення правил охорони водних ресурсів та водокористування (ст. 59-62 КУпАП);

5) правопорушення, пов'язані 3 незаконним використанням лісосічного фонду, заготівлею i вивезенням деревини, пошкодженням, знищенням чи забрудненням зелених насаджень (ст. 63-77 та 83-1 КУПАП);

6) правопорушення зі штучного забруднення атмосфери та викидів шкідливих газів (ст. ст. 78-81 та 91-6 КУпАП);

7) правопорушення щодо поводження 3 відходами на різних етапах їх використання, зберігання чи перероблення та використання хімічних речовин (ст. ст. 82-83 та 91-3 КУпАП)

8) правопорушення проти рослинного та тваринного світу (ст. 85-90 КУпАП);

9) правопорушення, пов'язані з відмовою від надання чи несвоєчасним наданням екологічної інформації(ст. 91-4 КУпАП);

10) правопорушення щодо невиконання законних розпоряджень чи приписів посадових осіб органів, які здійснюють державний контроль у галузі охорони навколишнього природного середовища, використання природних ресурсів, радіаційної безпеки або охорони природних ресурсів (ст. 188-5 КУпАП).

Таким чином, у контексті запобігання нераціональному споживанню та використанню оманливої господарської практики "greenwashing" КУпАП дозволяє обмежене використання ст. 91-4, яка передбачає за відмову від надання чи несвоєчасне надання за запитами повної та достовірної 
екологічної інформації накладення штрафу від трьох до десяти неоподатковуваних мінімумів доходів громадян.

Обмеженість ї̈ застосування випливає із урахування підвідомчості справ про адміністративні правопорушення. Так, відповідно до ст. 242-1 КУпАП розгляд справ про адміністративні правопорушення за вищевказаною статтею покладено лише на Центральний орган виконавчої влади, що реалізує державну політику зі здійснення державного нагляду (контролю) у сфері охорони навколишнього природного середовища, раціонального використання, відтворення та охорони природних ресурсів.

Як вже зазначалось, аналіз положення цього органу та природоохоронного законодавства свідчить про відсутність напряму діяльності з нагляду за відсутністю достовірної інформації на екологічних товарах чи послугах, отже, ймовірність її застосування у вказаному контексті лишається низькою.

Низька ймовірність можливості застосування цивільно-правової відповідальності за порушення екологічного законодавства на підставах, зазначених у ст. 69 Закону України «Про охорону навколишнього природного середовища», була розглянута вище.

Стосовно аналізу розділу VIII Кримінального кодексу України (далі КК України), що передбачає основи кримінальної відповідальності за екологічні порушення ст. ст. 236-254 КК України дозволяє зробити висновок, що передбачені ним напрями боротьби зі злочинами проти довкілля фактично дублюють за своїм змістом адміністративні порушення, що визначено КУпАП, і відрізняються в основному лише тяжкістю та небезпечністю скоєних кримінальних правопорушень у галузі екологічної безпеки. Питання оманливих практик в сфері торгівлі екологічною продукцією та нераціонального споживання в КК України не розглядаються.

Отже, проведений аналіз природоохоронного законодавства та відповідальності за їі порушення дозволив виявити, що воно майже виключно орієнтовано на протидію прямій шкоді природному середовищу життю і здоров'ю людей, завданої матеріальним виробництвом, при цьому питання раціонального споживання (за винятком кількох декларацій) та протидії оманливій господарській практиці “greenwashing” (за винятком сертифікації та маркування органічних продуктів) цим законодавством майже не врегульовано. Відповідно, на рівні центрального органу виконавчої влади 3 реалізації державної політики зі здійснення державного нагляду (контролю) у сфері охорони навколишнього природного середовища, раціонального використання, відтворення та охорони природних ресурсів вищезазначені напрями діяльності не розглядаються.
Своєю чергою у Законі України «Про основні принципи та вимоги до органічного виробництва, обігу та маркування органічної продукції» можна дослідити, що нагляд за додержанням цього Закону покладено на Державну службу України з питань безпечності харчових продуктів та захисту споживачів.

Питання надання оманливої інформації для споживачів регулюється: Законом України «Про захист прав споживачів», Законом України «Про рекламу», Законом України «Про захист економічної конкуренції», а питання недобросовісної конкуренції - Господарським Кодексом України та актами антимонопольного законодавства.

Так, ч. 7 ст. 15 Закону України «Про захист прав споживачів» передбачено право споживача у разі придбання продукції, яка не має потрібних споживачеві властивостей через отримання недостовірної інформації про продукцію, розірвати договір і вимагати відшкодування завданих йому збитків.

Пряма заборона нечесної підприємницької практики, що вводить в оману, міститься в ч. 3 статті 19 зазначеного Закону, а в ч. 6 зазначається, що «Правочини, здійснені з використанням нечесної підприємницької практики, є недійсними».

Водночас аналіз статті 23 цього закону свідчить про відсутність додаткових санкцій до суб'єкта господарювання, що використовує оманливі заяви, крім можливості вимагати від суб’єкта господарювання розірвати договір і вимагати відшкодування завданих йому збитків.

Також доцільно істотно переформатувати главу 15 Господарського Кодексу України в контексті ㄲï орієнтації на питання використання природних ресурсів на всіх етапах життєвого циклу продукції та розширити коло врегульованих питань з урахуванням екологічних аспектів. Слід приділити увагу внесенню змін до Розділу VI «Особливості правового регулювання в окремих галузях господарювання Господарського Кодексу України» для врегулювання питань щодо екологічних аспектів в окремих галузях. Наприклад, щодо особливостей фінансування екологічного виробництва. Також у розділі можуть бути розв'язані окремі питання стандартизації та маркування «зеленої» продукції, проведення екологічної експертизи тощо.

Питання публічних закупівель «зеленої» продукції, на нашу думку, можливо врегулювати через внесення змін до статті 75.

Питання залучення іноземних «зелених» інвестицій, а також моніторингу та звітності щодо їх ефективності, доречно врегулювати главою 38 «Іноземні інвестиції» Розділу VII Зовнішньоекономічна діяльність Господарського Кодексу України. 
У контексті врегулювання питань щодо усунення зі споживчого ринку оманливої господарської практики "greenwashing" внести зміни до Глави 3 "Обмеження монополізму та захист суб єктів господарювання і споживачів від недобросовісної конкуренції» [9].

Висновки та пропозиції. Таким чином, було встановлено, що в України фактично відсутні органи влади, функціонал яких передбачає можливість формування та реалізації державної екологічної політики в контексті забезпечення розвитку раціональних моделей споживання (за винятком раціонального використання природних ресурсів суб'єктами господарювання) та запобігання оманливій господарській практиці "greenwashing".

Отже, в Україні екологічними питаннями у цьому контексті фактично займаються органи, для яких природоохоронна діяльність не є визначеним їх профільними нормативно-правовими актами пріоритетом. Ці питання вирішуються такими органами безсистемно, в контексті їх основних завдань діяльності. Так, Міністерство освіти і науки України, займаючись питаннями освіти і просвіти в екологічній сфері, може на свій розсуд включити зазначене питання до своїх навчальних програм. Оскільки питанням раціонального споживання та оманливих господарських практик на рівні Міністерства захисту довкілля та природних ресурсів України, Державної екологічної інспекції України та основних актів природоохоронного законодавства увага майже не приділяється, то існує велика ймовірність недостатньої уваги цьому напряму і в затверджених навчальних програмах.

Реалізацією функції нагляду з запобігання оманливій практиці у сфері реалізації екологічних продуктів займаються:

1) в питаннях виготовлення, сертифікації та реалізації органічних продуктів - Державна служба України з питань безпечності харчових продуктів та захисту споживачів;

2) в питаннях захисту конкуренції від оманливих практик - Антимонопольний комітет України;

3) в питаннях відшкодування збитків та можливості розірвання договору-купівлі продажу та повернення сплачених грошей (за нібито органічні або екологічні товари та послуги) - Державна служба України з питань безпечності харчових продуктів та захисту споживачів.

Можливість колаборації та поєднання зусиль різних державних органів та недержавних громадських об'єднань є загальноприйнятою європейською практикою. Той факт, що в Україні для вирішення проблематики раціоналізації споживання та запобігання оманливій господарській практиці "greenwashing" можна залучити інші органи державної влади, не складає жодної проб- леми, але проблему складає відсутність належного законодавчого підгрунтя, сформованої екологічної політики за цім напрямом та державного органу, відповідального за її реалізацію. Також є проблеми 3 координацією робіт за цим напрямом, відсутність чітко визначених виконавців та завдань з зазначеного питання в положеннях державних органів.

Тому за результатами дослідження можна рекомендувати:

1. Доповнити мету, принципи та завдання Закону України «Про охорону навколишнього природного середовища» положеннями щодо раціоналізації споживання, доступу до об'єктивної інформації про екологічні наслідки споживчого вибору та основних критеріїв визначення екологічної або органічної продукції, а також обов'язковості наявності повної, достовірної та своєчасної інформації на таку продукцію;

2. Доповнити в Законі України «Про охорону навколишнього природного середовища» екологічні права громадян України правом на доступ до екологічної та органічної продукції; на прозорість схем постачання такої продукції на споживчий ринок; на повну, достовірну та своєчасну інформацію про таку продукцію; на долучення до нагляду за ринком екологічних товарів;

3. Визначити у Законі України «Про охорону навколишнього природного середовища» інші органи державної влади та недержавні організації, що можуть бути залучені в реалізації окремих екологічних проблем, межи їх повноважень та порядок координації та взаємодії;

4. Заборонити у Законі України «Про охорону навколишнього природного середовища" використання оманливих практик "greenwashing" та визначити відповідальність, пропорційну обсягам реалізованої продукції та набутої вигоди;

5. За принципами, закладеними в Закон України «Про основні принципи та вимоги до органічного виробництва, обігу та маркування органічної продукції», розробити та прийняти Закон України «Про екологічне виробництво, обіг та маркування екологічної продукції»;

6. Внести зміни до Положень Міністерства захисту довкілля та природних ресурсів України та Державної екологічної інспекції України, в яких врегулювати питання формування екологічної політики з раціоналізації, споживання та координації її реалізації;

7. Змінити формат Державної екологічної інспекції України на формат Державної екологічної служби, доповнивши контрольно-наглядові функції можливістю надання державних екологічних послуг;

8. Внести зміни до Положень Державної служби України з питань безпечності харчових продуктів та захисту споживачів та Антимонопольного 
комітету України, доповнивши їх завдання екологічними аспектами нагляду за продукцією та конкуренцією;

9. До Господарського Кодексу України внести зміни до статей та розділів, запропоновані у цій статті.

\section{Jimepamypa}

1. Братковська К.О. Щодо енергетичної моделі сталого споживання теплової енергії. Ефективна еконоліка. 2015. №15 URL: http:// www.economy.nayka.com.ua/ $\mathrm{op}=1 \& \mathrm{z}=4592$.

2. Лесь А.В., Ращенко А.В., Смаглій В.О. Відповідальне споживання в умовах сталого розвитку. Ефективна економіка. 2019. №1 URL: http:// www.economy.nayka.com.ua/pdf/1_2019/38.pdf.

3. Грищенко О.Ф. та Голишева Є.О. Використання грінвошингу як технології екологізації бізнесу: поняття, детермінанти та драйвери. Науковий вісник Міжнародного гуманітарного університету. 2020. Випуск № 46. С. 47-54.

4. Fiialka S.B. Greenwashing in communication with consumers on the ukrainian market. Поліграфія $i$ видавнича справа. 2017. № 1. С. 116-128.

5. Pimonenko T., Liulov O., Liulova L. Marketing instruments to promote green investment: declining greenwashing. Economic scopet. 2018. № 140. Pp. 204-213.

6. Міхайлуца М.К., Дугієнко Н.О. «Зелені» інвестиції через «зелені» облігації». Приазовський еко номічний вісник. 2020. Випуск № 3 (20). С. 29-33.

7. Лыга А.И. Потенциал применения системы защиты прав потребителей для обеспечения экологической безопасности города. MIND Journal. 2020. Issue No. 9. URL: https://mindjournal.wseh.pl/sites/default/ files/article/09-20/potencial_primeneniya_sistemy_ zashchity_prav_potrebiteley_dlya_obespecheniya_ ekologicheskoy bezopasnosti goroda.pd $\bar{f}$.

8. On self-service democracy: Configurations of individualizing governance and self-directed citizenship URL: https://journals.sagepub.com/doi/ abs $/ 10.1177 / 1368431012459693$.

10. Лига А.І. Проблеми екологізації господарського права: в контексті усунення оманливої господарської практики "greenwashing". Tреті наукові читання пал'яті акаделіка В.К. Малутова. 2021 р. Наук. ред. В.А. Устименко. Київ : НАН України.

11. $§ 8$ Beseitigung und Unterlassung/ Gesetz gegen den unlauteren Wettbewerb/ An official website of Das Bundesministerium der Justiz und $\mathrm{f}$ V Verbraucherschutz URL: https://www.gesetze-im-internet.de/uwg 2004/.

12. Закон України «Про охорону навколишнього природного середовища». Офіиійний Веб-сайт Верховної Ради України. URL: https://zakon.rada.gov.ua/ laws/show/1264-12\#Text.

13. Закон України «Про основні засади (стратегія) державної екологічної політики України на період до 2030 року». Офіційний Веб-сайт Верховної Ради Украӥни. URL: https://zakon.rada.gov.ua/laws/ show/2697-19\#Text.

14. Берзіна С.В., Капотя Д.Ю., Бузан Г.С. Екологічна сертифікація та маркування товарів і послуг. Методичний довідник. 2017. Київ. С. 58. URL: https:// mepr.gov.ua/files/docs/Ekolohichne_markuvannya/ ecolabel_book.pdf.

15. Ошурков С. Неоподатковуваний мінімум - 2021 рік та раніше. БУХУЧЕТ. 2021. URL: https://www.buhoblik.org.ua/nalogi/nalogovoepravo/493-neopodatkovuvanij-minimum-2013.html

\section{Анотація}

Лига А. I. Розвиток екологічної системи в контексті раціоналізації моделей споживання та запобігання оманливій господарській практиці "greenwashing". Стаття.

У статті визначено основні завдання, що має вирішувати законодавство в контексті забезпечення формування та реалізації раціональних моделей споживання, а також запобігання оманливій господарській практиці "greenwashing", зокрема нормотворче врегулювання таких питань: екологічна та споживча освіта та просвіта; підвищення обізнаності споживачів щодо наслідків їх вибору продукції та іï достовірного інформаційного забезпечення; залучення громадськості та підвищення його впливу на всіх етапах прийняття рішень щодо екологічної продукції, а також залучення до нагляду за нею; екологічні критерії державних закупівель; екологічне та органічне маркування; гармонізація, верифікація «зелених заяв» та стандартизація вимог до екологічного або органічного маркування; відповідальність за оманливу рекламу та інформацію про екологічну продукцію; прозорість діяльності та звітність суб'єктів господарювання; попередження практики штучного старіння, низької якості продукції тощо; запровадження практик екологічної корпоративної відповідальності та саморегулювання, долучення до екологічних стандартів; механізми сприяння суб'єктам господарювання, які комплексно переглядають свою практику закупівель, виробництва, продажу та утилізації продукції; державного нагляду за ринком екологічної продукції, та механізмів відповідальності за оманливі господарські практики.

Досліджено вміст законодавчого регулювання вищезазначених питань як в українському природоохоронному законодавстві, так і в інших нормативноправових актах з суміжних сфер та можливості їх правозастосування. Визначено органи влади, повноваження яких дозволяють розв'язувати проблему раціоналізації споживання та усунення з ринку недобросовісних господарських практик, що руйнують чесну конкуренцію на ринку екологічних товарів.

Проведений аналіз природоохоронного законодавства та відповідальності за ії порушення дозволив виявити, що воно майже виключно орієнтовано на протидію прямій шкоді природному середовищу життю i здоров'ю людей завданої матеріальним виробництвом, при цьому питання раціонального споживання (за винятком кількох декларацій) та протидії оманливій господарській практиці "greenwashing" (за винятком сертифікації та маркування органічних продуктів) цим законодавством майже не врегульовано. Тому обгрунтовано необхідність застосування норм інших нормативно-правових актів для врегулювання зазначених питань.

Також було встановлено, що на рівні центрального органу виконавчої влади з реалізації державної політики зі здійснення державного нагляду (контролю) у сфері охорони навколишнього природного середовища, раціонального використання, відтворення та охорони природних ресурсів, вищезазначені напрями діяльності не розглядаються. Для протидії оманливим практикам "greenwashing" та нераціональному споживанню використовуються державні органи, для яких природоохоронна діяльність не $є$ визначеним нормативно-правовими актами пріоритетом. Ці питання вирішуються такими органами безсистемно, в контексті основних завдань їх діяльності. 
Зроблені висновки щодо недоліків законодавства в контексті зазначеної мети дослідження дозволили надати пропозиції щодо його вдосконалення.

Ключові слова: раціональне споживання, оманлива господарська практика "greenwashing", споживачі, зелені заяви, екологічне маркування, органічне маркування.

\section{Summary}

Lyga $A$. I. Development of the ecological system in the context of rationalization of consumption models and prevention of deceptive economic practices "greenwashing". - Article.

The article identifies the main tasks to be solved by the legislation in the context of ensuring the formation and implementation of rational consumption models, as well as the prevention of deceptive economic practices of "greenwashing". In particular, the rule-making regulation of the following issues: environmental and consumer education and post-secondary education of consumers; raising consumer awareness of the consequences of their product choice and its veracious information support; involving the public and increasing its influence at all stages of decision-making on environmental products, as well as involvement in its supervision; environmental criteria for public procurement; ecological and organic labeling; harmonization, verification of "green applications" and standardization of requirements for environmental or organic labeling; responsibility for misleading advertising and information about environmental products; transparency of activities and reporting of business entities; prevention of the practice of artificial aging, low product quality, etc .; introduction of practices of ecological corporate responsibility and self-regulation, adherence to ecological standards; mechanisms to assist businesses that comprehensively review their procurement, production, sales and disposal practices; state supervision of the market of ecological products and mechanisms of responsibility for deceptive economic practices.

The content of legislative regulation of the abovementioned issue both in the Ukrainian environmental legislation and in other normative-legal acts and possibilities of its law-enforcement are investigated.

It was identifies Authorities wich powers allow to solve the problem of rationalization of consumption and elimination from the market of unfair economic practices that destroy fair competition in the market of environmental goods.

It was performed the analysis of environmental legislation and liability for its violation revealed that it is almost exclusively focused on counteraction direct damage to the environment and human health caused by material production, but theissue of rational consumption (except for a few declarations) and countering misleading economic practices "Greenwashing" (except for certification and labeling of organic products) is almost not regulated by this legislation. Therefore, the need to apply the rules of other regulations to address these issues is justified.

Also, it was found that at the level of the central executive body for the implementation of state policy on state supervision (control) in the field of environmental protection, rational use, reproduction and protection of natural resources, the above activities are not considered. In order to counteract the deceptive practices of "greenwashing" and irrational consumption, public authorities are used for which environmental activities are not a priority . These issues are resolved by such bodies unsystematically, in the context of their main tasks.

The conclusions made on the shortcomings of the legislation in the context of this goal of the study, allowed to make suggestions for its improvement.

Key words: rational consumption, deceptive economic practice of "greenwashing", consumers, green statements, eco-labeling, organic labeling. 